\section{Dr. C. Davison}

WITH the passing of Dr. Charles Davison on April 28, at the age of eighty-one, at Cambridge, seismology has lost another link with the great pioneers of modern seismology which include the names of Mallet, Milne, Knott, Oldham, Omori, Imamura, Davison and others.

Born on May 1, 1858, at a time when Milne was about seven years old, Davison was the second son of Fleet Paymaster E. C. Davison, and was educated at Armstrong College, Newcastle-on-Tyne, and at Emmanuel College, Cambridge. He spent much of his life as mathematics master at King Edward's High School, Birmingham, and was the author of "Higher Algebra" and "Subjects for Mathematical Essays".

Davison's writings on earthquakes covered a very wide field, including standard and popular books, numerous technical papers and popular articles. $\mathrm{He}$ was the leading authority on British earthquakes, 1,191 of which, ranging over a thousand years, he dealt with in his book "A History of British Earthquakes". He had also described the Hereford earthquake of December 17, 1896, and written "A Study of Recent Earthquakes". In 1921 he completed his "Manual of Seismology" and later wrote books on "Great Earthquakes" and "Studies in the Periodicity of Earthquakes".

Since the time Milne was professor of geology and mining at 'Tokyo, Davison was continuously interested in Japanese earthquakes and Japanese seismologists, some of whom visited him in England. He was the author of the book on "The Japanese Earthquake of 1923" and has written shorter descriptions of many other Japanese earthquakes. The subjects of Davison's scientific and technical papers printed by the seismological societies of many countries, and contained in many geological, philosophical and other periodicals, covered descriptions of individual earthquakes, the history of seismology, velocities of seismic waves, sea waves arising from earthquakes, earthquake sounds, earthquake-recording instruments, earthquake distribution, deep-focus earthquakes, twin earthquakes, volcanic earthquakes, earthquake intensity scales for drawing isoseismal lines and others, the list being by no means exhaustive. To all these subjects he added something of importance. Should it ever become possible to predict the exact time, place and energy of an earthquake, precautions could be taken in advance and many lives and much property saved. Davison no doubt always had this in mind, since on July 31,1930 , he contributed an article to The Times on "Earthquakes and Human Life", and he has frequently since 1891 returned to his task of attempting to find any periodicities there may be in the occurrence of earthquakes. He often had occasion to consider the origin of earthquakes, and in 1887 contributed a paper to the Philosophical Transactions of the Royal Society of London on "The Distribution of Strain in the Earth's Crust resulting from Secular Cooling", to which G. H. Darwin added a note. For forty-six years, until shortly before his death, Davison was a frequent contributor to NATURE on seismological topics.
Before the days of self-recording seismographs Davison did many experiments with pendulums, and often vividly recalled the times when, between two days work, he frequently sat up all night watching his instruments, occasionally being rewarded by the thrill of seeing them move, due to the action of waves from a distant earthquake. For many years he was secretary of the British Association Earth Tremors (now Seismological) Committee, and on the occasion of the recent visit of the Association to Cambridge in 1938 , Dr. F. J. W. Whipple and I visited him at his home. Unfortunately, on account of his age, Davison did not feel equal at the time to attending the meetings. He was passionately fond of music and literature, and had an excellent library of gramophone records of Beethoven's works. On March 19, 1934, The Times published an article by him on "Robinson Crusoe's Earthquake".

In 1886, Davison married Margaret Blanche Harris, of Great Chart, Ashford, Kent, and had a son and two daughters.

E. THLOTSON.

I FIRST met Dr. Davison in 1902, when I joined the staff of King Edward's School, Birmingham. At that time the mathematical teaching of the School was under the guidance of a very distinguished teacher, Mr. Rawdon Levett. In the summer of 1903, Dr. Davison succeeded him as senior mathematics master. He made little or no changes in the organization of the teaching, and during the next twelve years a steady stream of able mathematicians passed from the School to the universities. Among them were the last two Senior Wranglers.

Dr. Davison was a tireless worker with a wonderful mastery of detail. He always made use of odd times. Much of his literary work was done in his class room between morning and afternoon school, when other members of the staff would be chatting in the common room. One at least of his many books was entirely written in this way. The report of an earthquake made him very busy, and one of his last pieces of work before he retired was, I remember, an investigation into the transmission of sounds due to the Silvertown explosion during the War of 1914-18.

When he retired from scholastic work in 1920 , Davison had well prepared the ground for further academic distinctions. I, who had the privilege of succeeding him and carrying on the mathematical teaching of the School, am glad to put on record. how much I owe to his inspiration and wise counsel during the years I served under him. C. H. RICHARDS.

WE regret to announce the following deaths :

Prof. C. L. Boulenger, professor of zoology, Bedford College, University of London, on May 19, aged fifty-four years.

Mr. W. H. Massey, M.V.O., formerly consulting engineer to H.M. the King, on May 13, aged ninety.

Mr. Roger Smith, formerly electrical engineer to the Great Western Railway, president of the Institution of Electrical Engineers in 1919, aged seventyseven years. 